\title{
Board Governance and Performance: An Exploratory Study of Malaysian Cooperative Organizations
}

\author{
Rohana Othman ${ }^{1}$, Roslani Embi ${ }^{2}$, Nooraslinda Abdul Aris ${ }^{3}$, Siti Maznah Mohd Arif ${ }^{4}$, \\ Huang Ching Choo ${ }^{5}$ and Norashikin Ismail ${ }^{6}$ \\ ${ }^{1}$ Accounting Research Institute \& Faculty of Accountancy, Universiti Teknologi MARA, Malaysia \\ 2,3,4,5,6 Faculty of Accountancy, Universiti Teknologi MARA, Malaysia
}

Correspondence should be addressed to: Rohana Othman; rohana799@salam.uitm.edu.my

Received date: 11 October 2015; Accepted date: 10 December 2015;

published date: 22 September 2016

Copyright (C) 2016. Rohana Othman, Roslani Embi, Nooraslinda Abdul Aris, Siti Maznah Mohd Arif, Huang Ching Choo and Norashikin Ismail. Distributed under Creative Commons CC-BY 4.0

\begin{abstract}
Cooperatives are expected to help generate economic growth; become competitive business entities; and remain as effective self-help organizations while upholding sensitivity towards the environment. However, cooperatives like their business cousins in the public corporations are plagued with governance issues (Shaw, 2006). This has prompted studies to isolate the probable causes of their predicament. The issue of corporate governance of cooperatives has begun to become mainstream in research, and conventional wisdom dictates that governance procedures and processes that abound in the corporate world can prudently be applicable in the governance of cooperatives (Cornforth, 2004). In a cooperative, the Board of Directors plays a pivotal role in safeguarding the collective interest of the members (Jussila, Goel, \& Tuominen, 2012). The Board of Directors needs to demonstrate adequate and effective monitoring of the organizations they are helming. This paper examines the role of Board of Directors as custodian against financial fiasco in cooperatives organizations. This study focuses on the association of the size of Board of Directors of cooperatives and the frequency of board meetings with performance. Outcomes from the study indicated both the size of the board and the frequency of board meetings have no relationship with performance of cooperatives organizations in Malaysia. The results suggest that the board of directors may no longer be effective in managing the cooperatives towards achieving their members' objectives. Various literatures supported this finding. This result indicates that governance of cooperatives is in dire need of revision to increase its effectiveness.
\end{abstract}

Keywords: Cooperative Organizations, Board Size, Board meetings, cooperative governance, Performance)

Cite this Article as: Rohana Othman, Roslani Embi , Nooraslinda Abdul Aris, Siti Maznah Mohd Arif, Huang Ching Choo and Norashikin Ismail (2016)," Board Governance and Performance: An Exploratory Study of Malaysian Cooperative Organizations", Journal of Southeast Asian Research, Vol. 2016 (2016), Article ID 430025, DOI: $10.5171 / 2016.430025$ 


\section{Introduction}

The co-operative initiative began as a noble pursuit to provide common economic and social benefits to members. In recent decades, news of co-operative failures and insolvency became common place. In every post mortem report and white paper, these collapses were attributed to the lack or absence of adequate prudent corporate governance to detect and prevent incompetent management, fraudulent and financial improprieties, abuses, conflicts of interests and myriad other felonious acts which eventually culminated in the downfall of these co-operatives. These mismanagement, financial scandals and the breakdown of democracy, has raised concerns on the quality of co-operative governance (Lees \& Volkers, 1996). To compound matters, members' confidence in the board of directors charged with monitoring the cooperative management performance and representing the interest of members has eroded (Borgstro, 2013). While reflecting anemic levels of member participation, the democratic legitimacy and effectiveness of boards have begun to be seriously questioned, in particular the competency of board members to effectively supervise senior managers, ensure probity and protect the interests of members and other relevant stakeholders (Cornforth, 2004).

Co-operatives failures not only dampen economic and social development but are accompanied by devastating effects to a wide group of stakeholders (members, government, workers, and creditors among others). Malaysia has witnessed financial fiascos in a number of co-operatives resulting in crippling losses and the collapse of many co-operatives since 1975, ushering debilitating social and economic implications (Consumer Association of Penang, n.d.). The deterioration in the state and performance of various cooperatives in Malaysia has increased awareness among the concerned publics and researchers on governance of cooperatives. It was highlighted in the
Journal of Critical Perspectives on Accounting (2012) that research on cooperatives attracted some attention in the 1970s, but academic interest on it has since declined. The same appears to be true of Malaysia where studies focusing on Malaysian co-operatives have been quite lethargic. This said, and in considering previous financial scandals associated with Malaysian co-operatives, a study responding to a call on corporate governance in cooperatives would be appropriate.

Measuring performance is particularly important as a control function in an organization (Boehlje, 1992). A cooperative's financial performance can potentially influence the likelihood of management committing corporate fraud. According to Kellogg \& Kellogg (1991), cooperatives with poor financial performance would induce management to engage in fraud activities to ensure their job security and compensation. Research on co-operative financial performance normally is more prone to deal with issues on governance. Specifically, the bulk of the problems and challenges cooperatives face today dwells on fundamental inadequacies in governance including that related to Boards' roles and responsibilities.

In co-operatives, agency problems potentially exist between managers and cooperatives members (Cook, 1994). The principal-agent problem results from the separation of ownership and control in any type of firm (Milgrom \& Roberts, 1992; Rees, 1985). Managers, who control the cooperative, may have different goals from the members. The free rider problem, due to joint asset ownership (Sen, 1966) too plagues co-operatives since members do not bear the full cost of their actions. Then there are governance issues stemming from the democratic nature of co-operatives, potentially leading to a lack of expertise among Board members (Cook, 1994), and stability and viability problems when a cooperative can hire non-members (Ben-Ner, 1984). All these issues lead to the failure of

Rohana Othman, Roslani Embi , Nooraslinda Abdul Aris, Siti Maznah Mohd Arif, Huang Ching Choo and Norashikin Ismail (2016), Journal of Southeast Asian Research, DOI: 10.5171/2016.430025 
the co-operative form of organizations (Hansmann, 2009). Board of directors is an important ingredient in solving the agency problem that occurs in an organization (Fama \& Jensen, 1983). The Board of directors plays a major role in making sure that the shareholder's interest is well protected. Thus, the Board of Directors provides an important corporate governance function as it is part of the top corporate hierarchy in the firm's organizational structure (Kim \& Nofsinger, 2007). Based on previous research, the Board of Directors has been stated as one of the internal governance instruments in minimizing the agency costs (Matoussi \& Gharbi, 2011).

Bond (2009) opined corporate governance concepts and approaches from the corporate literature can be applied to cooperatives since they are a form of a corporation. In fact, board members of both firm types perform similar duties and share in upholding similar responsibilities such as looking out for the member/owner's (shareholder's) best interests. Therefore, this study will focus on the number in the Board of Directors' (board size), number of Board meetings and cooperative performance. There are several board governance features that should be considered, but this research only focuses on two (2); (1) board size and (2) board meeting. The question to be addressed in this study viz. co-operative in Malaysia is: Do board size and frequency of board meetings have a relationship with the performance of the cooperatives? Based on the research question identified, the study aims to examine the relationship between board size and frequencies of board meetings with performance of cooperative organizations.

\section{Literature Review}

The literature on cooperatives yields numerous definitions of cooperatives. A cooperative can be broadly defined as "an autonomous association of persons united voluntarily to meet their common economic, social and cultural needs and aspirations through jointly owned and democratically controlled enterprise" (MacPherson, 1995). Helm (1968) defines Cooperative Societies as registered voluntary associations of persons with membership not less than ten persons, with a common interest formed and operated along democratic principles, for the purpose of economic and social interests, at optimal costs to its members who contribute the capital and manage the business so established by delegating some powers to elected management. This common ownership and shared aspirations intensify the prerequisite for transparency and accountability in terms of corporate governance.

In Malaysia, the development of the cooperatives has been quite impressive. The National Cooperative Policy (NCP) 20112020 launched by Prime Minister Datuk Seri Mohd Najib Tun Abdul Razak attests the government's recognition for the cooperative movement's role in economic development. As an extension of the original policy on cooperatives, the NCP takes it a step further by setting forth plans to strengthen the role of cooperatives within the context of national development. As such, cooperatives are tasked to not just uplift the standard of living for their members but also to support the national development agenda (Ministry of Domestic Trade, Cooperatives and Consumerism website, www.kpdnkk.gov.my).

Empirical evidence has focused on the interaction between organization performance and board characteristics particularly on the ideal number of directors. Lipton \& Lorsch (1992) suggested an ideal number of eight or nine is less likely to be manipulated by the elected chairman. Jensen (1993) recommended a board size of eight, finding larger boards have greater difficulty reaching a quorum. He surmised that when groups grow larger, they lose their effectiveness. Despite the perceived advantage of having a larger human resource pool, the sheer size gives rise to problematic and complicated coordination and processes. 
It follows then that, as the board increases in size, it may lose its effectiveness.

Rauterkus (2003) appeals to Jensen (1993) in her argument that eight is an ideal board size and uses logistic regression analysis to find evidence that larger boards are more likely to file for Chapter 11 restructuring. Prior studies on board size have also highlighted the influence board size may have on board involvement in company affairs (Singh \& Davidson III, 2003). Board size may influence the ability of the board to be effective in managing and monitoring the management of the company, hence enhanced performance of organizations. Board size has been examined by a number of researchers (Hermalin \& Weisbach, 1991; Pfeffer, 1972; Yermack, 1996). However, the outcomes to support this contention have been mixed. According to Chaganti et. al. (1985), larger board size can affect corporate performance. Lanser (1969) concurred that larger boards influence corporate performance. Dalton et. al. (1999) and Kiel \& Nicholson (2002) asserted that companies with a large board size would have more opportunities for networking, bring more knowledge, experience, and skill in order to improve company performance. Further, Adams \& Mehran (2003) and Rahman \& Ali (2006), found a positive and significant relationship between board size and firm performance as measured by Tobin's $Q$.

Other researchers, however, found nothing to signify a relationship between board size and performance (Hermalin \& Weisbach, 1991; Van Ees, Postma, \& Sterken, 2003). Conversely, Yermack (1996) found that a large board size has a small, insignificant and negative effect on performance. Guest (2009) suggests that a company could be more effective with a small board size because it would reduce the problem of poor communication and piggybacking on the boards. Ibrahim \& Samad (2011) found a negative relationship between board size and firm performance. Mak \& Kusnadi (2005), in analyzing the relationship between board size and firm performance in Singapore and
Malaysia, found a negative relationship between the board sizes and performance using Tobin's $Q$ measurement for performance. In addition, Eisenberg, Sundgren, \& Wells (1998) document evidence that there is a negative relationship between the size of the board and profitability for small and medium size firms in Finland. Other studies further support this notion, which confirmed that large boards are not as effective as small boards (Ibrahim \& Samad, 2011). Brewer et. al., (2000) and Chen et al. (2006) also claimed that there is no empirical evidence on the impact of board size on financial information quality or firm performance.

Boards of directors need to demonstrate adequate and effective monitoring of the organizations they are helming. One way to demonstrate that board members had participated to monitor closely the management during regular board meetings is to oversee seriously the operation of the entities. According to the Malaysian Code of Corporate Governance (MCCG, 2007), the board should meet regularly in order to discuss issues regarding the corporation's activities. The meeting information such as the number of meetings and details of attendance should be disclosed in the annual report. Board meeting refers to the frequency of board meetings within the year. Shivdasani \& Zenner (2004) suggested that a high frequency of board meetings is required to ensure high supervision and control. Chen et al. (2006) stated that the high number of board meetings might show that the boards are aware about the company's activities. Lipton \& Lorsch (1992) and Byrne (1996) studied the relationship between board meetings and effective monitoring. The researchers found boards that meet regularly are more active in making sure that the corporation is running toward the best interest of the shareholders. Kamardin \& Haron (2011) also noted that a high frequency of board meeting shows the directors know about the corporations' activities and are able to monitor the implementation of the strategy in that 
corporation. Conger, Finegold, \& Lawler (1998) suggest that frequent board meetings will improve the effectiveness of a board. However, Jensen (1993) argued that board meetings cannot be used in determining the effectiveness of the boards because there are other factors that need to be considered. Chen et al., (2006) support Jensen (1993) where their studies showed there is no significant influence between frequency of board meetings and performance. Vafeas, (2003), found that frequent meetings only lead to poor performance of a company.

\section{Methodology}

\section{Sampling}

This is an exploratory study on governance in cooperative organizations in Malaysia. The sample selected for this study consists of the top 100 cooperative organizations in Malaysia based on the classification made by the Malaysian Cooperative Commission. The top one hundred cooperative organizations identified are from different types of cooperatives such as trading, agriculture, manufacturing, investment, among others. The types of cooperatives are identified according to the activities of each cooperative organization. Clifford \& Evans (1997) took a sample of 100 companies, randomly selected from the top 500 Australian companies (from various sectors). The data for this study are mainly gathered from the annual reports for the year 20112012. However, only thirty-nine annual reports of cooperative organizations in Malaysia for the year 2011-2012 are available. Many cooperative organizations did not or have not submitted their annual reports. Based on the Malaysian Cooperative Society Act 1993, the cooperative organizations are not required to submit their annual report. A majority of the cooperative organizations submitted their annual report voluntarily.

\section{Statistical Analysis}

Descriptive statistics

Table 1: Cooperatives Sample by Types of Activities

\begin{tabular}{|l|c|c|}
\hline \multicolumn{1}{|c|}{ Industry Sector } & No of Cooperatives & $\mathbf{\%}$ \\
\hline Credit & 20 & 39.2 \\
\hline Agriculture & 8 & 15.7 \\
\hline Services & 8 & 15.7 \\
\hline Banking & 4 & 7.8 \\
\hline Transportation & 3 & 5.9 \\
\hline Housing & 3 & 5.9 \\
\hline Consumerism & 2 & 3.9 \\
\hline Construction & 1 & 2.0 \\
\hline Farming & 1 & 2.0 \\
\hline Health & 1 & 2.0 \\
\hline Total & 51 & 100 \\
\hline
\end{tabular}

Rohana Othman, Roslani Embi , Nooraslinda Abdul Aris, Siti Maznah Mohd Arif, Huang Ching Choo and Norashikin Ismail (2016), Journal of Southeast Asian Research, DOI: 10.5171/2016.430025 
A summary of the cooperatives sample composition in this study is presented in Table 1.1. From the table, credit cooperatives represented the highest number of cooperative activities with 20 credit cooperatives (39.2\%) followed by agriculture and services, each having 8 cooperatives (15.7\%). The banking sector was represented by 4 cooperatives (7.8\%), while the transportation and housing sectors had 3 representatives each $(5.9 \%)$. The sample included 2 representatives from consumerism (3.9\%) and the construction, farming and health sectors rounded the remainder of the sample with 1 representative each (2.0\%).

Tables 1.2 and 1.3 present the descriptive analyses for size of the board of directors and frequency of board meetings respectively. Table 1.2 showed 14 or $27.5 \%$ of the cooperative organizations in the sample had 12 members in the board, 8 cooperatives $(15.7 \%)$ had board size comprising 15 members and 2 cooperatives has a board size of 6 members. Section 42 of the Malaysian Cooperative Society Act 1993 stipulated that cooperative organizations should have a minimum of 6 and a maximum of 15 members on their boards. Simultaneously, Table 1.3 shows that 2 cooperatives boards had frequent meetings at 27 times in a year while there were 10 cooperatives that conducted 6 meetings. It can be generally implied cooperatives with high frequencies of board meetings has high supervision and control and thereby is able to monitor the implementation of organizational strategies (Chen et al., 2006; Kamardin \& Haron, 2011; Shivdasani \& Zenner, 2004).

Table2: Number of Board members

\begin{tabular}{|c|c|c|c|c|c|}
\hline & & Frequency & Percent & $\begin{array}{c}\text { Valid } \\
\text { Percent } \\
\end{array}$ & $\begin{array}{c}\text { Cumulative } \\
\text { Percent } \\
\end{array}$ \\
\hline \multirow[t]{11}{*}{ Valid } & 6 & 2 & 3.9 & 3.9 & 3.9 \\
\hline & 8 & 1 & 2.0 & 2.0 & 5.9 \\
\hline & 9 & 7 & 13.7 & 13.7 & 19.6 \\
\hline & 10 & 7 & 13.7 & 13.7 & 33.3 \\
\hline & 11 & 3 & 5.9 & 5.9 & 39.2 \\
\hline & 12 & 14 & 27.5 & 27.5 & 66.7 \\
\hline & 13 & 4 & 7.8 & 7.8 & 74.5 \\
\hline & 14 & 4 & 7.8 & 7.8 & 82.4 \\
\hline & 15 & 8 & 15.7 & 15.7 & 98.0 \\
\hline & 17 & 1 & 2.0 & 2.0 & 100.0 \\
\hline & Total & 51 & 100.0 & 100.0 & \\
\hline
\end{tabular}

Rohana Othman, Roslani Embi , Nooraslinda Abdul Aris, Siti Maznah Mohd Arif, Huang Ching Choo and Norashikin Ismail (2016), Journal of Southeast Asian Research, DOI: 10.5171/2016.430025 
Table 3: Frequency of Board meetings

\begin{tabular}{|c|c|c|c|c|c|}
\hline & & Frequency & Percent & $\begin{array}{c}\text { Valid } \\
\text { Percent }\end{array}$ & $\begin{array}{c}\text { Cumulative } \\
\text { Percent }\end{array}$ \\
\hline \multirow[t]{17}{*}{ Valid } & 5 & 4 & 7.8 & 7.8 & 7.8 \\
\hline & 6 & 10 & 19.6 & 19.6 & 27.5 \\
\hline & 7 & 1 & 2.0 & 2.0 & 29.4 \\
\hline & 8 & 1 & 2.0 & 2.0 & 31.4 \\
\hline & 10 & 1 & 2.0 & 2.0 & 33.3 \\
\hline & 11 & 2 & 3.9 & 3.9 & 37.3 \\
\hline & 12 & 7 & 13.7 & 13.7 & 51.0 \\
\hline & 13 & 3 & 5.9 & 5.9 & 56.9 \\
\hline & 14 & 5 & 9.8 & 9.8 & 66.7 \\
\hline & 15 & 4 & 7.8 & 7.8 & 74.5 \\
\hline & 16 & 7 & 13.7 & 13.7 & 88.2 \\
\hline & 17 & 1 & 2.0 & 2.0 & 90.2 \\
\hline & 20 & 1 & 2.0 & 2.0 & 92.2 \\
\hline & 21 & 1 & 2.0 & 2.0 & 94.1 \\
\hline & 24 & 1 & 2.0 & 2.0 & 96.1 \\
\hline & 27 & 2 & 3.9 & 3.9 & 100.0 \\
\hline & Total & 51 & 100.0 & 100.0 & \\
\hline
\end{tabular}

Table 4: Descriptive Statistics of the Variables

\begin{tabular}{|l|c|r|r|r|r|}
\hline & N & \multicolumn{1}{|c|}{ Minimum } & \multicolumn{1}{c|}{ Maximum } & \multicolumn{1}{|c|}{ Mean } & Std. Deviation \\
\hline $\begin{array}{l}\text { Number } \\
\text { of Board } \\
\text { members }\end{array}$ & 51 & 6 & 17 & 11.75 & 2.432 \\
\hline $\begin{array}{l}\text { Frequenc } \\
\text { y of Board } \\
\text { Meetings }\end{array}$ & 51 & 5 & 27 & 12.31 & 5.537 \\
\hline Net_Profit & 51 & -RM7,045,855 & RM1,729,775,000 & RM51,356,571.32 & RM245,140,582.161 \\
\hline
\end{tabular}

The results in Table 1.4 indicate that overall the study variables mean scores range from low to moderate. Number of board members $(M=11.75)$ appears to have moderate mean scores. The moderate mean score for the number of board members 
indicates that the board members will not be as effective in managing and monitoring the management as well as having less opportunity for networking thus stifling sharing of knowledge and experience. As a result, directors themselves will not upgrade their own skills in governance and monitoring the management to protect the interests of the members and improve their skills.

Concurrently, frequency of board meetings $(M=12.31)$ indicate low mean scores. The low mean score for Board meetings is an indicator that the Board of directors did not demonstrate adequate and effective monitoring of the cooperative organizations they are helming. Lipton \& Lorsch (1992) and Byrne (1996) highlighted that boards that meet regularly are more active in ensuring that the organization is run towards the best interests of the members.

\section{Correlation Results}

Table 5: Correlations between board members and number of board meetings with Net Profit Margin as a measure of Performance

\begin{tabular}{|c|c|c|c|c|}
\hline & & BOD Size & $\begin{array}{c}\text { BOD } \\
\text { Meetings }\end{array}$ & Net_Profit \\
\hline \multirow[t]{3}{*}{ BOD Size } & Pearson Correlation & 1 & -.186 & .069 \\
\hline & Sig. (2-tailed) & & .192 & .633 \\
\hline & $\mathbf{N}$ & 51 & 51 & 51 \\
\hline \multirow{3}{*}{$\begin{array}{l}\text { BOD } \\
\text { Meetings }\end{array}$} & Pearson Correlation & -.186 & 1 & -.035 \\
\hline & Sig. (2-tailed) & .192 & & .809 \\
\hline & $\mathbf{N}$ & 51 & 51 & 51 \\
\hline \multirow[t]{3}{*}{ Net_Profit } & Pearson Correlation & .069 & -.035 & 1 \\
\hline & Sig. (2-tailed) & .633 & .809 & \\
\hline & $\mathbf{N}$ & 51 & 51 & 51 \\
\hline
\end{tabular}

A bivariate correlation was conducted between net profit and the size of the board of directors and the number of board meetings. As shown in Table 1.5, both results of the correlation indicate that there is a little positive correlation between net profit and the size of the board of directors and, net profit and the number of board meetings and both are not significant $(\mathrm{r}=$ $.069, \mathrm{p}=.633$ and $\mathrm{r}=-.035, \mathrm{p}=.809$ respectively).

In summary, the results indicate that board size and the number of board meetings in a year do not significantly affect the performance of the cooperative organizations. The results suggest that the board of directors may no longer be effective in managing the cooperatives towards achieving their members' objectives. Various literatures supported this finding. A cooperative is a democratic organization, owned and controlled by their members/users (Novkovic, 2008). Although democracy provided cooperative members with voice and active participation in cooperative organizations, the lack of interest among members has resulted in deterioration of the democratic process (Borgstro, 2013). In a manner of speaking, 
an indifference to the affairs of the cooperativesindicates members do not engage themselves in the operations and management of cooperatives, opting to leave the matters to the management to make decisions as deemed fit to their intentions. Shaw (2006) also highlighted the diminishing role of the members of cooperatives in governance. In this situation, it provides opportunities for agency problems to occur because managers have different goals from members. According to Cuevas \& Fischer (2006), failure in cooperative financial institutions occurs as a result of a conflict between member/owner and the management. In this respect, Cornforth (2004) further emphasized that power in cooperative organizations during normal times usually remains with the CEO. He highlighted that the board is little more than a 'rubber stamp' for management's decision, essentially having a symbolic role to legitimize management's action. Mace (1971) had earlier mentioned a similar predicament existing among large corporations. Kennedy \& Itkonen (1996) suggested that power and decision making in cooperatives are often concentrated in too few hands at the top. He further noted cooperatives performances have long suffered from a lack of participation and sense of involvement while statutory governing bodies exist to endorse management decision instead of challenging policies and strategies. Besides, it was also highlighted in the literature that cooperative organizations are facing lack of expertise among their board members (Cook \& Chaddad, 2004).

\section{Conclusion}

This paper examined how existing concepts of corporate governance can be extended to help understand the governance of cooperatives. The argument is that, separately, each theory is too one-dimensional, only highlighting a particular aspect of the board's role. Empirical research on non-profit boards suggests governance is a complex, inherently difficult and problematic activity. As a number of governance scholars have recently noted, we need to find new ways of thinking about governance that move beyond narrow theoretical frameworks.

Dunn, et al. (2002), in their study, found that owner-directors of cooperatives often make decisions based on internal politics rather than on sound economics. Cooperative directors may be motivated to make decisions that benefit individuals at the expense of the cooperative. This insight may help explain why governance issues are exaggerated at cooperatives relative to corporations. Staatz (1983) highlighted that, unlike shareholders, cooperatives' members' preferences are not necessarily homogeneous. He further elaborates that shareholders simply want to maximize the value of their share values while goals from patronage can differ from member to member at a cooperative and may include maximizing returns, utilizing cooperative services, or finding a home for their production.

The results of this study provide evidence that governance of cooperatives is relational in nature based on trust and mutual accountability. The implications from this situation may differ in comparison to contractual governance where contractual governance is acknowledged to lead to improved operations, management and the bottom line.

One can deduce then that the relationship between the boards of directors of cooperatives in terms of corporate governance transcends size or the number of times the board meets in a year. Perhaps this can lend support to the argument that corporate governance of cooperatives needs to be relooked and adopt the governance concepts and mechanisms currently applicable to public corporations.

The spirit of collectivism in cooperatives reflects the democratic character of the organization. The democratic undertone permeates every aspect of a cooperative 
including decision-making, conflict resolution, shared understanding and managing expectations. It follows then that managing successful corporations, including cooperatives is the culmination of managing expectations and minimizing imbalances through prudent governance (Jussila, 2012).

\section{Acknowledgement}

We would like to thank Accounting Research Institute and Ministry of Education Malaysia for grants to finance this research.

\section{References}

1. Adams, R., Mehran, H. (2003). Is corporate governance different for bank holding companies? FRBNY Economic Policy Review $9,123-142$

2. Ben-Ner, A. (1984). On the stability of the cooperative type of organization. Journal of Comparative Economics, 8(3), 247-260.

3. Boehlje, M. (1992). Alternative Models of Structural Change in Agriculture and Related Industries. Agribusiness, Vol. 8, No. 3, 219231 (1992).

4. Bond, J. K. (2009). Cooperative financial performance and board of director characteristics: A quantitative investigation. Journal of Cooperatives, 22, 22-44.

5. Borgstro, M. (2013). Effective cooperative governance: A practitioner 's perspective. Journal of Co-operative Organization and Management. 1, 49-50.

6. Chaganti, R. S., Mahajan, V., \& Sharma, S. (1985). Corporate Board Size, Composition And Corporate Failures In Retailing Industry. Journal of Management Studies, 22(4), 400417.

7. Chen, G., Firth, M., Gao, D. N., \& Rui, O. M. (2006). Ownership structure, corporate governance, and fraud: Evidence from China. Journal of Corporate Finance, 12(3), 424-448.
8. Clifford, P., \& Evans, R. (1997). NonExecutive Directors: A Question of Independence. Corporate Governance: $A n$ International Review, 5(4), 224-231.

9. Conger, J. A., Finegold, D., \& Lawler, E. E. (1998). Appraising boardroom performance. Harvard Business Review, 76, 136-164.

10.Consumer Association of Penang. (n.d.). History of cooperative scandals. Retrieved from

http://www.consumer.org.my/index.php/fo cus/cooperative-scandals/391-history-ofcooperative-scandals

11.Cook, M. L. (1994). The role of management behavior in agricultural cooperatives. Journal of Agricultural Cooperation, 9, 42-58.

12.Cook, M. L., \& Chaddad, F. R. (2004). Redesigning cooperative boundaries: The emergence of new models. American Journal of Agricultural Economics, 86(5), 1249-1253.

13.Cornforth, C. (2004). The governance of cooperatives and mutual associations: a paradox perspective. Annals of Public and Cooperative Economics, 75(1), 11-32.

14.Cuevas, C. E., \& Fischer, K. P. (2006). Cooperative financial institutions: Issues in governance, regulation, and supervision (No. 82). World Bank Publications.

15.Dalton, D. R., Daily, C. M., Johnson, J. L., \& Ellstrand, A. E. (1999). Number of directors and financial performance: A meta-analysis. Academy of Management Journal, 42(6), 674686.

16.Eisenberg, T., Sundgren, S., \& Wells, M. T. (1998). Larger board size and decreasing firm value in small firms. Journal of Financial Economics, 48(1), 35-54.

17.Fama, E. F., \& Jensen, M. C. (1983). Agency problems and residual claims. Journal of law and Economics, 26(2), 327-349. 
18.Guest, P. M. (2009). The impact of board size on firm performance: evidence from the UK. The European Journal of Finance, 15(4), 385-404.

19.Hansmann, H. (2009). The ownership of enterprise. Harvard University Press.

20.Helm, F. C. (1968). The economics of cooperative enterprise. London : Univ. of London P.

21.Hermalin, B. E., \& Weisbach, M. S. (1991). The effects of board composition and direct incentives on firm performance. Financial Management, 101-112.

22.Ibrahim, H., \& Samad, F. A. (2011). Corporate Governance Mechanisms and Performance of Public-Listed FamilyOwnership in Malaysia. International Journal of Economics and Finance, 3(1), p105.

23.Jensen, M. C. (1993). The modern industrial revolution, exit, and the failure of internal control systems. The Journal of Finance, 48(3), 831-880.

24.Jussila, I., Goel, S., \& Tuominen, P. (2012). Governance of Co-operative Organizations: A Social Exchange Perspective. Business and Management Research, 1(2), p14.

25. Kamardin, H., \& Haron, H. (2011). Internal corporate governance and board performance in monitoring roles: evidence from Malaysia. Journal of Financial Reporting and Accounting, 9(2), 119-140.

26. Kellogg, I., \& Kellogg, L. B. (1991). Fraud, window dressing, and negligence in financial statements (Vol. 1). Shepards/McGraw-Hill.

27.Kim, K. A., \& Nofsinger, J. R. (2007). Corporate Governance (Second Edi.). New Jersey: Pearson Education Inc.

28.Lanser, R. (1969). Visible traits of boards of directors. Unpublished doctoral dissertation. Stanford University.
29.Lees, M., \& Volkers, R. (1996). General Trends, Findings \& Recommendations. Review Of International Cooperation, 89, 3749.

30.Lipton, M., \& Lorsch, J. W. (1992). A modest proposal for improved corporate governance. The Business Lawyer, 59-77.

31.Mace, M. L. (1971). Directors: Myth and reality. Division of Research, Graduate School of Business Administration, Harvard University Cambridge MA.

32.Mak, Y. T., \& Kusnadi, Y. (2005). Size really matters: Further evidence on the negative relationship between board size and firm value. Pacific-Basin Finance Journal, 13(3), 301-318.

33.Matoussi, H., \& Gharbi, I. (2011). Board Independence And Corporate Fraud: The Case of Tunisian Firms. Working paper. The Economic Research Forum. Giza:Egypt.

34.Milgrom, P. R., \& Roberts, J. (1992). Economics, organization and management (Vol. 7). Prentice-Hall Englewood Cliffs, NJ.

35.Novkovic, S. (2008). Defining the cooperative difference. The Journal of SocioEconomics, 37(6), 2168-2177.

36.Pfeffer, J. (1972). Size and composition of corporate boards of directors: The organization and its environment. Administrative Science Quarterly, 218-228.

37.Rauterkus, S. Y. (2003). Do Weak Internal Corporate Control Systems Lead to Failure? White Paper, Department of Finance, Louisiana State University, Aug.

38. Rees, R. (1985). The theory of principal and agent part i. Bulletin of Economic Research, 37(1), 3-26.

39.Sen, A. K. (1966). Labour allocation in a cooperative enterprise. The Review of Economic Studies, 33(4), 361-371. 
40.Shaw, L. (2006). Overview of corporate governance issues for co-operatives. Discussion paper. Global Corporate Governance Forum. London. February 2007.

41.Shivdasani, A., \& Zenner, M. (2004). Best practices in corporate governance: what two decades of research reveals. Journal of Applied Corporate Finance, 16(2-3), 29-41.

42.Singh, M., \& Davidson III, W. N. (2003). Agency costs, ownership structure and corporate governance mechanisms. Journal of Banking \& Finance, 27(5), 793-816.

43.Staatz, J. M. (1983). The cooperative as a coalition: a game-theoretic approach.
American Journal of Agricultural Economics, 65(5), 1084-1089.

44.Vafeas, N. (2003). Further evidence on the compensation committee composition as a determinant of CEO compensation. Financial Management, 53-70.

45.Van Ees, H., Postma, T. J. B. M., \& Sterken, E. (2003). Board characteristics and corporate performance in the Netherlands. Eastern Economic Journal, 29(1), 41-58.

46.Yermack, D. (1996). Higher market valuation of companies with a small board of directors. Journal of financial economics, 40(2), 185-211. 